\title{
EVALUATION OF ANTIBACTERIAL, ANTIOXIDANT, AND ANTICANCER POTENTIALS FROM MARINE RED ALGAE GRACILARIA CORTICATA
}

\author{
JAYASREE $\mathbf{P}^{1}$, THIRUCHELVI $\mathbf{R}^{1 *}$, BALASHANMUGAM $\mathbf{P}^{2}$
}

${ }^{1}$ Department of Bio-Engineering, School of Engineering, Vels Institute of Science, Technology and Advanced Studies, Pallavaram, Chennai - 600 117, Tamil Nadu, India. ${ }^{2}$ Avanz Bio Pvt. Ltd., Chennai - 600 059, Tamil Nadu, India. Email: thiruchelvi.se@velsuniv.ac.in

Received: 28 March 2018, Revised and Accepted: 05 May 2018

\section{ABSTRACT}

Objective: The present study was to evaluate the biological activity of Red algae, Gracilaria corticata, collected from the southeast coast of Mandapam, Ramanathapuram, Tamil Nadu. Seaweeds are rich in bioactive compounds. Seaweeds are highly diverse group of organism from secondary metabolites of the natural source are a potential source. The marine seaweed is the interesting group of their broad spectrum of biological activities such as antibacterial, antioxidant, and anticancer.

Methods: The antibacterial activity of G. corticata was tested against Staphylococcus aureus and Escherichia coli by disk diffusion method. In vitro antioxidant activity was determined by 1,1-diphenyl-2-picrylhydrazyl (DPPH) radical scavenging assay. 3-(4,5-dimethylthiazol-2-yl)-2,5diphenyltetrazolium bromide assay was employed to study the anticancer activity against (MDA-MB 231) human breast cancer cell line.

Results: The DPPH assay screening of methanolic extract of G. corticata showed specific activity of inhibition. In antibacterial shows the growth of two virulent strains of pathogenic bacteria, E. coli and Bacillus subtilis. In anticancer activity obtained results indicated that the methanol extracts of G. corticata were cytotoxic against (MDA-MB231) human breast cancer cell.

Conclusion: These results show that G. corticata has a great biological potential, which could be considered for future uses in pharmaceutical, food, and cosmetics purpose.

Keywords: Seaweeds, Gracilaria corticata, Antibacterial, Antioxidant, Anticancer.

(C) 2018 The Authors. Published by Innovare Academic Sciences Pvt Ltd. This is an open access article under the CC BY license (http://creativecommons. org/licenses/by/4. 0/) DOI: http://dx.doi.org/10.22159/ajpcr.2018.v11i7.26311

\section{INTRODUCTION}

In recent years, natural products have been playing a major role in search of novel drugs against many infectious diseases, inflammation, cancer, and many other complex illnesses. They are considered as treasure for researchers due to their enormous structural diversity and complexity. The marine algae or seaweed represents a largely untapped source for the isolation of novel bioactive compounds [1].

Seaweeds are the primitive angiosperm that has incomparable mineral source, particularly marine red and brown algae. They are used as commercial products; stabilizers, thickeners, emulsifiers, foods, etc. In recent years, phycologists focus the bioactive substances of marine plants because of the presence of macro and trace elements and their cell wall composition. Seaweeds or marine algae are classified into three main categories: Brown algae (Phaeophyta), green algae (Chlorophyta), and red algae (Rhodophyta) [2]. Thus, macroalgae have been recognized as a promising ultimate source of bioactive secondary metabolites with antitumor [3], antibacterial, antioxidant, anti-inflammatory, anticancer, anticholesterolemic activity, antidiabetic activity, and hepatoprotective activity [4]. Several red algae contain agar as a water-soluble sulfated galactan located in the intercellular spaces. Agar is a mixture of polysaccharide, which can be composed of agarose and agaropectin with similar structural and functional properties as carrageenan of red algae [5]. Thus, the study was to assess antibacterial, antioxidative, and anticancer potentialities of $G$. corticata settled along the Mandapam coast of Tamil Nadu.

\section{METHODS}

\section{Collection of sample}

The sample $G$. corticata (Red algae) was collected from intertidal zone of Mandapam coast (Lat. 9¹7"N; Lon. 79¹9"E) of Gulf of Mannar, southeast coast of Tamil Nadu, India. The collected sample was cleaned with seawater to remove the epiphytes and sand particle, and the sample has been packed in polythene bag and brought to laboratory. Then, the sample was washed with freshwater and shade dried. The shade dried sample is stored.

\section{Sample identification}

The seaweeds were identified and authenticated by Dr. Ganesan, Senior Scientist, Central Salt and Marine Research Institute, Mandapam Camp, Ramanathapuram, Tamil Nadu, India (Fig. 1).

\section{Preparation of extract}

\section{Methanol extraction}

The acetone extract of $G$. corticata was extracted using $50 \mathrm{~g}$ of the power sample with $150 \mathrm{ml}$ of acetone. The mixture was placed in the orbital shaker for $24 \mathrm{~h}$ at $32^{\circ} \mathrm{C}$ in room temperature. After squeezing, the solvent was taken out and extraction liquid was filtered using Whatman filter paper. The extracted sample was condensed using Soxhlet extractor at $50^{\circ} \mathrm{C}$.

\section{Aqueous extraction}

The aqueous extract of seaweed $G$. corticata was dried. After drying, $3 \mathrm{~g}$ of seaweed is measured and pulverize it gently. Then, add $50 \mathrm{ml}$ of distilled water to the added seaweed in the conical flask. The solution was filtered using Whatman filter paper and the filtered solution was condensed using Soxhlet extractor. The solution was stored in a refrigerator for further use as crude extract of aqueous.

\section{Antibacterial activity}

The G. corticata tested against various Gram-positive and Gram-negative strains using agar disc diffusion technique with Escherichia coli and Bacillus subtilis both bacterial culture were smeared in the agar disc 
is used to see the antibacterial activity. The antibacterial activity was carried out using a standard disc diffusion technique with concentration of $25 \mu \mathrm{L}, 50 \mu \mathrm{L}, 75 \mu \mathrm{L}$, and $100 \mu \mathrm{L}$ crude extract of Gracilaria corticata with control of $21 \mu \mathrm{L}$ zetamycin was used. These were allowed to dry under aseptic condition and incubated at $37^{\circ} \mathrm{C}$ for $24 \mathrm{~h}$. The diameter of clear zone around the discs was measured as antibacterial activity (Table 1 and Fig. 2) [6].

\section{Antioxidant activity}

\section{$D P P H$ free radical assay}

The assay for DPPH scavenging activity was described by Rattyetal. [6]. The sample was reacted with the stable DDPH radical in a methanol solution. The reaction mixture consisted of different concentrations of sample and $2 \mathrm{ml}$ of DPPH radical solution ( $0.4 \mathrm{mM})$. When DPPH reacts with an antioxidant compound which can donate hydrogen, it is reduced. The reaction mixture was incubated at 20 min in dark condition. The changes in color (from deep violet to light yellow) were read absorbance at $517 \mathrm{~nm}$ using UV-vis spectrophotometer (Tables 2 and 3). The mixture of methanol and sample serves as blank. The control solution was prepared by mixing methanol and DPPH radicals [7]. The scavenging activity percentage $(\mathrm{AA} \%)$ was determined according to the formula:

$(\mathrm{AA} \%=[$ control-sample $] /$ control $* 100)$

\section{Cell culture}

The extracts were tested on McCoy cell. The cancer cell line was collected and grown in Dulbecco's modified eagle modified eagle medium (DMEM) with fetal bovine serum. Cells were seeded in 96-well and allowed to adhere for $24 \mathrm{~h}$ at $37^{\circ} \mathrm{C}$, with $\mathrm{CO}_{2}$, in an incubator. Then, one of it serially diluted samples in medium was dispensed into the wells of the cell plates and incubated for a further $72 \mathrm{~h}$. After removal of the sample medium, the cells were added with DMEM medium and incubated. After $72 \mathrm{~h}$, cells were fixed with cold $40 \%$ trichloroacetic acid at $4^{\circ} \mathrm{C}$ for $1 \mathrm{~h}$ and washed with water. The absorbance was measured,

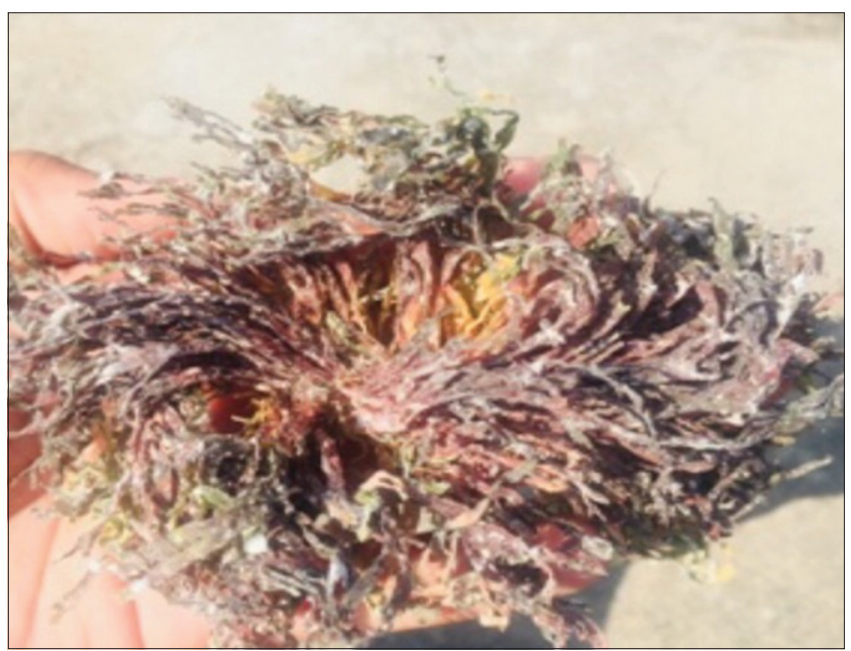

Fig. 1: Gracilaria corticata
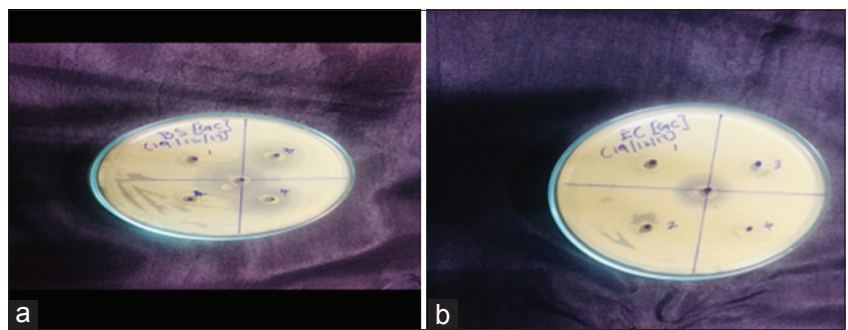

Fig. 2: Antibacterial activity of Gracilaria corticata by crude methanol extract. (a) Gram-positive (Bacillus subtilis). (b) Gramnegative (Escherichia coli) absorbance of the samples was measured using a microplate enzymelinked immunosorbent assay reader at wavelength at $492 \mathrm{~nm}$ [8]. Percentage of dead cells was calculated in comparison to control. The concentration of the extracts that inhibition of cells growth was determined in Table 4.

Determination of cell viability (3-(4,5-dimethylthiazol-2-yl)-2,5diphenyltetrazolium bromide [MTT] assay)

The anticancer activity of drug tested against breast cancer cell line (MDA-MB 231) by MTT assay.

The MDA-MB 231 cells seeded in 96-well microplates $\left(1 \times 10^{6}\right.$ cells/well) and incubated at $37^{\circ} \mathrm{C}$ for $24 \mathrm{~h}$ in $5 \% \mathrm{CO}_{2}$ incubator and allowed to grow $90 \%$ confluence. Then, the medium was replaced, and the cells were treated with drug at different concentrations such as $20,40,60,80$, and $100 \mu \mathrm{g} / \mathrm{mL}$ and incubated for $24 \mathrm{~h}$. The cells were then washed with phosphate-buffer saline (PBS, pH - 7.4) and MTT solution (5 mg/mL) was added to each well. The plates were then stored at $37^{\circ} \mathrm{C}$ in the dark for additional 2-4 h. The formazan crystals were dissolved in $100 \mu \mathrm{L}$ DMSO, and the absorbance was read spectrometrically at $570 \mathrm{~nm}$. The percentage of cell viability was expressed as in formula. The concentration that inhibited $50 \%$ of cell growth was referred as $\mathrm{IC}_{50}$ value, which was used as a parameter for cytotoxicity study. The morphological changes of untreated (control) and the cells treated were observed under bright field microscope after $24 \mathrm{~h}$ [9] (Table 5 and Fig. 3).

Cell viability $(\%)=\frac{\text { Absorbance of treated cells }}{\text { Absorbance of control cells }} \times 100$

\section{RESULTS AND DISCUSSION}

The antibacterial activity of $G$. corticata was determined in both Gram-positive and Gram-negative bacteria. The crude methanol

Table 1: Antibacterial activity of Gracilaria corticata

\begin{tabular}{lllll}
\hline \multirow{2}{*}{ Organism } & \multicolumn{4}{l}{ Concentration of the extract } \\
\cline { 2 - 5 } & $\mathbf{2 5} \boldsymbol{\mu L}$ & $\mathbf{5 0} \boldsymbol{\mu L}$ & $\mathbf{7 5} \boldsymbol{\mu L}$ & $\mathbf{1 0 0} \boldsymbol{\mu L}$ \\
\hline Escherichia coli & - & - & $18 \mathrm{~mm}$ & $20 \mathrm{~mm}$ \\
Bacillus subtilis & - & - & $14 \mathrm{~mm}$ & $19 \mathrm{~mm}$ \\
\hline
\end{tabular}

Methanol extract of Gracilaria corticata observed the inhibition zone of diameter and no activity of antibacterial against Escherichia coli and Bacillus subtilis

Table 2: Antioxidant activity by DPPH assay for crude methanol extract

\begin{tabular}{lll}
\hline Concentration $(\boldsymbol{\mu L})$ & Wavelength $(\mathbf{n m})$ & Absorbance $(\%)$ \\
\hline 100 & 517 & 14.52 \\
200 & 517 & 20.25 \\
300 & 517 & 32.76 \\
400 & 517 & 36.26 \\
500 & 517 & 44.15 \\
\hline
\end{tabular}

Crude methanol extract of Gracilaria corticata interprets with increase in concentration with increase in absorbance at $517 \mathrm{~nm}$

Table 3: Antioxidant activity by DPPH assay for crude aqueous extract

\begin{tabular}{lll}
\hline Concentration $(\boldsymbol{\mu L})$ & Wavelength $(\mathbf{n m})$ & Absorbance $(\%)$ \\
\hline 100 & 517 & 8.16 \\
200 & 517 & 17.81 \\
300 & 517 & 21.20 \\
400 & 517 & 31.60 \\
500 & 517 & 37.11 \\
\hline
\end{tabular}

Crude aqueous extract of Gracilaria corticata interprets with increase in concentration with increase in absorbance at $517 \mathrm{~nm}$ 


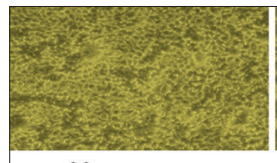

$20 \mu \mathrm{g}$

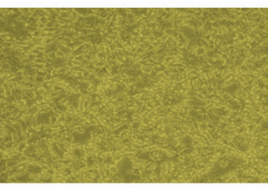

$80 \mu \mathrm{g}$

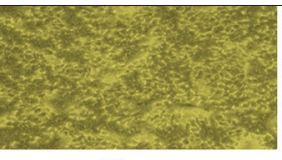

$40 \mu \mathrm{g}$

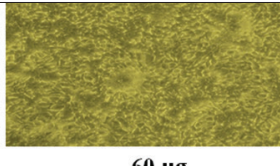

$60 \mu \mathrm{g}$

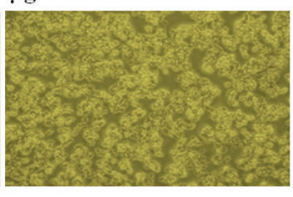

$100 \mu \mathrm{g}$

Fig. 3: Anticancer activity of Gracilaria corticata crude methanol extract of different concentrations

Table 4: Cytotoxicity activity of McCoy cell cancer

\begin{tabular}{llllll}
\hline Concentration & I & II & III & Average & \%inhibition \\
\hline 20 & 0.803 & 0.795 & 0.793 & 0.799 & 96.48 \\
40 & 0.742 & 0.750 & 0.759 & 0.750 & 90.83 \\
60 & 0.694 & 0.699 & 0.704 & 0.699 & 84.62 \\
80 & 0.614 & 0.608 & 0.62 & 0.614 & 74.33 \\
100 & 0.543 & 0.557 & 0.55 & 0.55 & 66.58 \\
\hline
\end{tabular}

Cytotoxicity activity of McCoy cell line was observed and inhibition activity of cell line interpreted

Table 5: Anticancer activity of Gracilaria corticata

\begin{tabular}{ll}
\hline Concentrations & \% cell viability \\
\hline $20 \mu \mathrm{g}$ & 95.67 \\
$40 \mu \mathrm{g}$ & 78.34 \\
$60 \mu \mathrm{g}$ & 64.19 \\
$80 \mu \mathrm{g}$ & 52.73 \\
$100 \mu \mathrm{g}$ & 39.29 \\
\hline
\end{tabular}

Anticancer activity of Gracilaria corticata was observed with the cell viability by decrease in concentration with increase in cell viability

extract shows the antibacterial activity. The zone of inhibition was produced by these extract against pathogenic microorganism. The Gram-positive bacterial highest zone inhibition is $19 \mathrm{~mm}$ at $100 \mu \mathrm{L}$. In Gram-negative bacterial highest zone of inhibition is $20 \mathrm{~mm}$ at 100 $\mu \mathrm{L}$. The zone formation shows increased concentration at $75 \mu \mathrm{L}$ and $100 \mu \mathrm{L}$ in both Gram-positive and Gram-negative bacteria (Table 1 and Fig. 1). The in vitro antibacterial activity of seaweeds extracted with methanol and aqueous was showed in various studies. The reviewed articles reported that antibacterial compounds are more active against Gram-positive bacteria than Gram-negative bacteria. The resistance of Gram-negative bacteria toward antibacterial substance was related to hydrophilic surface which is rich in lipopolysaccharide molecules, presenting a barrier to penetrate numerous antibiotic molecules. However, Gram-positive bacteria do not possess outer membrane and cell wall structure [10-12].

The antioxidant of the seaweed extracts was measured on the basis of the scavenging activity of the stable DPPH free radical. It shows active site of antioxidant in crude methanolic extraction by increasing of inhibition by increasing of concentration. As in crude aqueous extract, the antioxidant activity that shows the slight inhibition increase, with increase of concentration. The best progress result shows that antioxidant activity of crude extract of methanol in Gracilaria corticata (Tables 2 and 3). DPPH is considered as a good kinetic model for peroxyl radicals [13]. The antioxidants have main roles in scavenging the free radicals, maintaining the cell integrity, slow down ageing, and prevent the development of various complications associated with oxidative stress-related disease and cancer [14].

The criteria used to categorize the activity of extracts against human breast (McCOY) cell lines based on the values of cells (Table 4 and Fig. 2).
The anticancer activity against cancer cell line was inhibited with increased concentration of solvent crude extract. In breast cancer cell line (MDA-MB 231), more cytotoxic effect was observed in methanol extract in $24 \mathrm{~h}$ treatment. It showed that the increased concentration of drug presents good toxicity over cancer cell line. It had a maximum of $95.67 \%$ cell viability for $20 \mu \mathrm{g}$ of crude methanolic extract. Similarly, the drug showed its minimum of $39.9 \%$ cell viability of methanol extract. It represents that the increased concentration of drug presents good toxicity over breast cancer cell line (MDA-MB 231) (Table 5) [15,16].

\section{CONCLUSION}

Marine seaweeds have numerous bioactive compounds such as pathogens against antibacterial activity, DPPH assay activity, and anticancer activity. In this study, they are more significant and thus it suggests that the active components are responsible for antibacterial and antioxidant metabolites in seaweeds, and the results are found to be interesting. Thus, exploration of such biological agents might be a probable resource of an array of biologically active compounds, and the present results will ensure a starting point for exploiting natural bioactive substances present in the extracts of algae $[15,16]$. Seaweed plays a key role in reducing the breast cancer and other types of cancer. A mechanism in which cancer could be reduced or retard its rate of growth [17]. Further, work is in progress which aimed at the investigation of detailed studies on purification and evaluation of such compounds can take this to a large-scale application in pharmaceutical industries.

\section{ACKNOWLEDGMENT}

The author acknowledge the support of Dr. Ganesan, Senior Scientist, Central Salt and Marine Research Institute, Mandapam Camp, Ramanathapuram, Tamil Nadu, India, for authenticate the seaweed. Author also grateful for Dr. P. Balashanmugam, Principle, Scientist of Avanz Bio Pvt. Ltd., and would like to thank Mrs. R. Thiruchelvi, Faculty of Bioengineering, VISTAS, for the support and guidance.

\section{AUTHOR'S CONTRIBUTION}

Jayashree. P, Thiruchelvi. R, and Balashanmugam. P conceived and designed the experiment. Jayashree. $\mathrm{P}$ performed the experiment. Jayashree. P and Thiruchelvi. R worked together on manuscript writing.

\section{CONFLICTS OF INTEREST}

There are no conflicts of interest.

\section{REFERENCES}

1. Zbakh H, Chiheb I, Motilva V, Riadi H. Antibacterial, cytotoxic and antioxidant potentials of Cladophora prolifera (Roth) Kutzing Collected from the Mediterranean Coast of Morocco. Am J Phytomed Clin Ther 2014;2:1187-99.

2. Yende SR, Harle UN, Chaugule BB. Therapeutic potential and health benefits of Sargassum species. Pharm Rev 2014;8:1.

3. Mary JS, Vinotha P, Pradeep AM. Screening for in vitro cytotoxic activity of seaweed, Sargassum sp. against Hep-2 and MCF-7 cancer cell lines. Asian Pac J Cancer Prev 2012;13:6073-6.

4. Deepa S, Bhuvana B, Hemamalini S, Janet C, Kumar S. Therapeutic potential and pharmacological significance of the marine algae Gracilaria corticata. Pharm Biol Eval 2017;4:68-72.

5. Balakrishnan CP, Jenifer P, Esakkilingam M. Algal documentation and phytochemical studies of red algae Gracilaria corticata of Manapad Coast, Tamil Nadu. J Pharm Phytochem 2013;2(4).

6. Sasikala C, Ramani DG. Comparative study on antimicrobial activity of seaweeds. Asian journal of pharmaceutical and clinical research 2017;10:384-6.

7. Ratty AK, Sunamoto J, Das NP. Interaction of flavonoids with 1, 1-diphenyl-2-picrylhydrazyl free radical, liposomal membranes and soybean lipoxygenase-1. Biochem Pharmacol 1988;37:989-95.

8. Acharya NS, Shah UR, Shah RG, Acharya S, Hingorani L. Evaluation of in vitro anticancer activity of Symplocos racemosa bark against hepatocellular carcinoma. Int J Pharm Pharm Sci 2015; 7:384-5.

9. Skehan P, Storeng R, Scudiero D, Monks A, McMahon J, Vistica D, 
et al. New colorimetric cytotoxicity assay for anticancer-drug screening. JNCI J Natl Cancer Inst 1990;82:1107-12.

10. Shan B, Cai YZ, Brooks JD, Corke $H$. The in vitro antibacterial activity of dietary spice and medicinal herb extracts. Int J Food Microbiol 2007; 117:112-9.

11. Seenivasan R, Indu H, Archana G, Geetha S. The antibacterial activity of some marine algae from south east coast of India. J Pharm Res 2010;8:1907-12.

12. Kalemba DA, Kunicka A. Antibacterial and antifungal properties of essential oils. Curr Med Chem 2003;10:813-29.

13. Wu XJ, Hansen C. Antioxidant capacity, phenolic content, and polysaccharide content of Lentinus edodes grown in whey permeatebased submerged culture. J Food Sci 2008;73:M1-8.
14. Rackova L, Oblozinsky M, Kostalova D, Kettmann V, Bezakova L. Free radical scavenging activity and lipoxygenase inhibition of Mahonia aquifolium extract and isoquinoline alkaloids. J Inflammation 2007;4:15.

15. Sheeja L, Lakshmi D, Bharadwaj S, Parveen KS. Anticancer activity of phytol purified from Gracilaria edulis against human breast cancer cell line (MCF-7). Int J Curr Sci 2016;19:36-46.

16. Patia MP, Das Sharma S, Nayaka L, Pandab CR. Uses of seaweed and its application to human welfare: A review. Int J Pharm Pharm Sci 2016;8:12-20.

17. Patia MP, Das Sharma S, Nayaka L, Pandab CR. Uses of seaweed and its application to human welfare: A review. Int J Pharm Pharm Sci 2016;8:12-20 